\title{
Hematopoietic stem cells are a critical sub-population of whole bone marrow in the treatment of myocardial infarction
}

\author{
Philip Davy ${ }^{1,2}$, Brienne Walker ${ }^{1}$, Livingston Wong ${ }^{3}$, Richard Allsopp ${ }^{1}$ \\ ${ }^{1}$ Institute for Biogenesis Research, University of Hawai'i at Mānoa, Honolulu, USA; *Corresponding Author: pdavy@hawaii.edu \\ ${ }^{2}$ Department of Molecular Biosciences and Bioengineering, University of Hawai'i at Mānoa, Honolulu, USA \\ ${ }^{3}$ Transplant Institute of the Pacific, Hawai'i Medical Center East, Honolulu, USA
}

Received 27 February 2013; revised 25 March 2013; accepted 15 April 2013

Copyright (C) 2013 Philip Davy et al. This is an open access article distributed under the Creative Commons Attribution License, which permits unrestricted use, distribution, and reproduction in any medium, provided the original work is properly cited.

\begin{abstract}
Recent studies suggest that whole bone marrow (WBM) derived stem cells may facilitate recovery following myocardial infarction. However, the sub-population of WBM responsible for recovery remains uncertain. By adjusting the abundance of $\mathrm{CD} 34^{+} \mathrm{Lin}^{\mathrm{Neg}}$ cells in human bone marrow we examined the relative significance of hematopoietic stem cells (HSC) in the recovery of cardiac function in a murine model of induced myocardial infarction. Enrichment of HSC by $\sim 100$-fold in WBM transplanted into mice significantly increased recovery of heart function and reduced scar size compared to transplantation of WBM depleted in HSC by $\sim 10$-fold $(P<$ 0.05 , and $P<0.01$ respectively). Peri-infarct capillary density was significantly increased in recipients of HSC-enriched samples $(P<0.01)$ or WBM samples $(P<0.01)$ compared to controls. These results strongly suggest a critical role for HSC in the effective treatment of myocardial infarction with human bone marrow, and imply that enrichment of HSC may markedly benefit the clinical application of WBM treatments.
\end{abstract}

Keywords: Hematopoietic Stem Cells; Myocardial Infarction; Transplantation; Cardiac Disease

\section{INTRODUCTION}

Myocardial infarction (MI) is the leading cause of disease mortality worldwide [1]. MI is a common consequence of cardiovascular disease (CVD) and results in either immediate death in the acute phase (AMI) or prolonged deterioration of cardiac function that leads to fatal cardiac failure or arrest in chronic cases. An MI results from the occlusion of a coronary blood vessel, usually by an atherosclerotic plaque, and the damage of MI is primarily due to the resultant lack of perfusion of oxygen and nutrients to the downstream area of cardiac tissue. Conventional therapy has focused on the reperfusion of the affected region, stabilization of heart function, and measures to prevent recurrence.

Adult stem cells may have shown the potential to reduce the near-term loss of life and regenerate heart function after MI in small scale clinical studies [2-5]. Bone marrow is the most studied accessible source of adult stem cells, and over the last decade bone marrow cells have been assessed for their capacity to regenerate heart tissue and function in both animals and humans. However, bone marrow is an extremely complex organ comprised of multiple types of cells. The mix of cell types within bone marrow has given rise to disagreements about the possible roles they could play in the regeneration of cardiac tissue. There has been much debate over which cells, including HSC, may contribute to recovery of heart function. Transdifferentiation, cellular fusion, neovascularization, and immune modulation have been suggested as mechanisms of action for observed improvements resulting from treatment with bone marrow but uncertainty remains [6-9]. HSC reside primarily in bone marrow and give rise to all cells of the hematopoietic system. Various cluster of differentiation cell surface markers including CD34, CD90, CD133, and CD38 [10-12] have been used to phenotypically distinguish and purify HSC from other WBM cells in humans using florescent activated cell sorting (FACS). Extensive therapeutic utilization and the ability to purify HSC based on their defined surface phenotype makes them an attractive source of stem cells for cellular therapies.

A number of clinical trials have been performed to as- 
sess the utility of BM-derived samples in facilitating the recovery for cardiac damage. Controlled human trials including randomized, double blindstudies that involved administration of BM cells into coronary arteries have shown modest subsequent improvements to global heart function [13-15]. However, other studies performed under similar conditions have found no functional improvement for intracoronary delivery [16,17] and no positive effect following transendocardial delivery [18]. Mobilization of BM stem cells either as a natural response to injury [19] or with granulocyte colony-stimulating factor [20] show functional improvements, albeit limited, which may be linked to improved perfusion of the infarcted area. Mobilized CD34 ${ }^{+}$cells have been shown to contribute to vasculogenesis and cardiomyogenesis in rats [21], and have also been shown to have greater efficacy than total mononuclear cells [22]. Autologous $\mathrm{CD} 34^{+}$cells infused into the infarcted artery of acute MI patients in human trials showed a similar positive response to the findings in rat models [23], although this was not carried out in direct comparison to the total BM cell population. A 2012 meta-analysis of randomized controlled clinical trials concluded intracoronary delivery of BM cells significantly increased functionality and reduced MI reoccurrence [24]. Comparisons of the relative efficacies of different cells types have shown $\mathrm{BM}$ mononuclear cells to be more effective than BM mesenchymal stem cells (MSC) [25] and adult HSC to be more effective than cord blood stem cells [26]. However, the relative ability of HSC within WBM cell preparations to facilitate recovery from cardiac damage has not yet been assessed.

\section{MATERIALS AND METHOD}

\subsection{Bone Marrow Collection}

Bone marrow samples were obtained from an anonymous donor in collaboration with the Transplant Institute of the Pacific (Hawaii Medical Center East, Honolulu, HI). The Institutional Review Board cleared this study from oversight because all samples were obtained from deceased anonymous donors with the informed written consent of a direct family member.

\subsection{Preparation of Bone Marrow-Derived Samples}

Mononuclear cells were prepared from thawed bone marrow aspirates using the standard protocol for Ficoll density gradient separation using the GE Ficoll-Paque PREMIUM $^{\mathrm{TM}}$ (Pittsburgh, PA). The HSC (CD34 ${ }^{+} \mathrm{Lin}^{\mathrm{Neg}}$ ) depleted and enriched samples were obtained and assessed using a combination of magnetic activated cell sorting (MACS) and FACS. MACS was performed with the Lineage Cell Depletion Kit or CD34 ${ }^{+}$Microbead Kit
(MiltenyiBiotec; Auburn, CA) for HSC enrichment or depletion respectively. FACS analysis and sorting of HSC was performed on a Becton Dickinson Aria II using PE-CD34 and a PE-Cy5.5 lineage cocktail (see Table S1 for list of antibodies). LiveDead ${ }^{\mathrm{TM}}$ (Invitrogen; Carlsbad, CA) staining showed greater than $85 \%$ cell viability in the source WBM samples and was used to exclude dead cells during FACS.

\subsection{Mice}

Prkdc ${ }^{\text {scid }}$ Severe Combined Immune Deficient (SCID) mice (Jackson Laboratory; Bar Harbor, ME) were housed in aseptic caging in accordance with the guidelines of the Laboratory Animal Services at the University of Hawaii and the Committee on Care and Use of Laboratory Animals of the Institute of Laboratory Resources National Research Council (DHEW publication 80-23, revised in 1985). This study was reviewed by ACURO (USAMRMC Animal Care and Use Review Office) and received approval on Apr 30, 2009 (approval \#: 08052002).

\subsection{Echocardiography}

Short-axis m-mode echocardiograph analysis of heart function was performed on unanaesthetized mice as previously described [27] at -1 (baseline) and 30 days using a Vevo2100 ${ }^{\mathrm{TM}}$ ultrasound device (Visual Sonics Inc; Toronto, Canada) with an $18 \mathrm{MHz}$ transducer. The following measurements were taken via the software on the Vevo2100 10 machine (all in $\mathrm{mm}$ ): interventricular septum depth during diastole (IVS;d), left ventricular internal diameter during diastole (LVID;d), left ventricle posterior wall depth during diastole (LVPW;d), interventricular septum depth during systole (IVS;s), left ventricular internal diameter during systole (LVID;s) and left ventricular posterior wall depth during systole (LVPW;s). At each time point, ten separate heartbeats per mouse were analyzed to determine left ventricular ejection fraction (LVEF) as well as fractional shortening (FS). First the volume of the left ventricle during diastole and systole, LV Vol;d and LV Vol;s respectively, were determined, and those values were then used to calculate LVEF and FS.

$$
\begin{aligned}
& \text { LV Vol;d }=((7.0 /(2.4+\text { LVID;d })) \times \text { LVID; } 33) \\
& \text { LV Vol;s }=((7.0 /(2.4+\text { LVID;s })) \times \text { LVID;s3 }) \\
& \text { LVEF\% }=100 \times((\text { LV Vol; }- \text { LV Vol;s)/LV Vol;d }) \\
& \text { FS\% }=100 \times((\text { LVID; }- \text { LVID;s)/LVID;d })
\end{aligned}
$$

Analysis was performed for the following number of mice within each group; control $n=6$, HSC-depleted $n=$ 10 , whole bone marrow $\mathrm{n}=6$, and HSC-enriched $\mathrm{n}=10$.

\subsection{Cryoinjury}

The procedure for infarct induction using cryo-abla- 
tion was performed as previously described [28]. Briefly, isoflurane-anaesthetized mice were artificially ventilated using a small-rodent ventilator (Harvard Apparatus; Holliston, MA) throughout surgery. A thoracotomy was performed through the fourth left intercostal space, the pericardium was separated and opened, and the heart exposed. Cryoinfarction was produced by the application of a liquid nitrogen chilled probe of $2 \mathrm{~mm}$ in diameter to the free wall of the anterior left ventricle for 10 seconds. The exact position of the probe was carefully set using the left atrium and branches of the left cardiac vein as anatomic landmarks.

\subsection{Cell Transplantation}

Approximately 1 minute after the cryoinjury, $1.5 \times 10^{5}$ cells suspended in $30 \mathrm{ml}$ PBS or an equal volume of sterile PBS was injected using 30-gauge insulin needles in at least three positions of the peri-infarct area identified by a paling of the myocardium. Following wound closure the animals were removed from ventilation and placed in a bleach-sterilized, heated recovery chamber supplied with oxygen until they regained consciousness. Average mortality rates for this procedure were approximately ten percent, with excessive blood loss being the primary complication.

\subsection{Histology and Immunohistochemistry}

Thirty days after cryoinfarction, all mice were sacrificed and hearts were retrieved for immunohistochemical analysis. The following number of mice were processed for histology in each group; control $n=7$, HSC-depleted $\mathrm{n}=10$, whole bone marrow $\mathrm{n}=9$, and HSC-enriched $\mathrm{n}=$ 10. Briefly, the hearts were arrested in $5.4 \mathrm{mM} \mathrm{KCl}$ at $4{ }^{\circ} \mathrm{C}$ before 6 hours of fixation with fresh $4 \%$ paraformaldehyde. Prior to paraffin embedding, hearts were visualized for macroscopic indications of the infarct for later guidance with sectioning. Ten successive $5 \mathrm{~mm}$ sections were collected on 5 slides at intervals to obtain sections from the center of the infarction. Collagen deposition analysis of midline scar length, the circumference of scarred left ventricle midway between the epicardial and endocardial surfaces, using Mason's Trichrome staining [29] was used to assess infarct size. Revascularization of the peri-infarct zone was assessed by quantification of capillary density by a blind observer utilizing DAB visualization of endothelial cell specificIsolectin B4 staining [11]. Human nuclear antigen (HNA) immunostaining with DAPI counterstaining was performed to determine whether transplanted cells were retained within infracted hearts at the study endpoint. Images were taken on an Olympus BX41 ${ }^{\mathrm{TM}}$ microscope using Pictureframe ${ }^{\mathrm{TM}}$ software (version 2.3), and quantified and analyzed using ImageJ (version $1.44 \mathrm{n}$ ).

\subsection{In Vitro Functional Analysis of CD34 ${ }^{+}$in $^{\text {Neg }}$ Bone Marrow Cells}

The frequency of HSC in the CD $34^{+} \operatorname{Lin}^{\text {Neg }} \mathrm{WBM}$ population that was used to either enrich WBM or was depleted from WBM in this study was assessed using the cobblestone-area forming cell (CAFC) assay performed as previously described [30].

\subsection{Statistical Analysis}

Comparisons of data from all cohorts were conducted using one-way ANOVA and Student's $t$-test.

\section{RESULTS}

\subsection{Analysis of the Relative Contribution of HSC to the Recovery of Cardiac Function after Induced Myocardial Infarction}

To determine whether the HSC population of bone marrow contributes to functional recovery after MI, we generated BM samples differing in their HSC content: HSC MACS depleted, untreated whole bone marrow (WBM), and HSC MACS enriched. FACS analysis of the depleted, WBM, and enriched samples was used to determine the relative number of $\mathrm{CD} 34^{+} \mathrm{Lin}^{\mathrm{Neg}}$ cells. The depleted and enriched samples had an approximately 10 -fold reduction or 100 -fold increase in the numbers of HSC, respectively (Figure 1) relative to WBM. Sham MACS processed WBM samples were created by processing mononuclear cells without antibody labeling through a MACS column.

HNA co-staining with DAPI was performed to evaluate whether cells with human nuclei had persisted to the experimental endpoint in the peri-infarct zone of hearts of mice receiving the transplanted BM samples. Costaining revealed that hearts received both the HSC-depleted and HSC-enriched samples retained human cells at 30 days after treatment (Figure 2).

To establish whether treatment with $1.5 \times 10^{5}$ cells per animal for each sample had affected recovery after induced MI we assessed cardiac functional changes by performing echocardiography. Baseline measurements were taken from the pool of mice used in the experiment and endpoint measurements were taken prior to euthanasia. ANOVA revealed no significant difference between the groups' baseline data $\left(F=2.6<F^{\text {crit }}=2.9\right)$. There was a significant decrease in the left ventricular fractional shortening (LVFS) of the control group and the groups receiving HSC-depleted samples and WBM at four weeks after cryoinfarction compared to the baseline $(P<0.05)$. In contrast, heart function (as measured by LVFS) in the groups that received HSC-enriched samples was restored to levels not significantly different from 

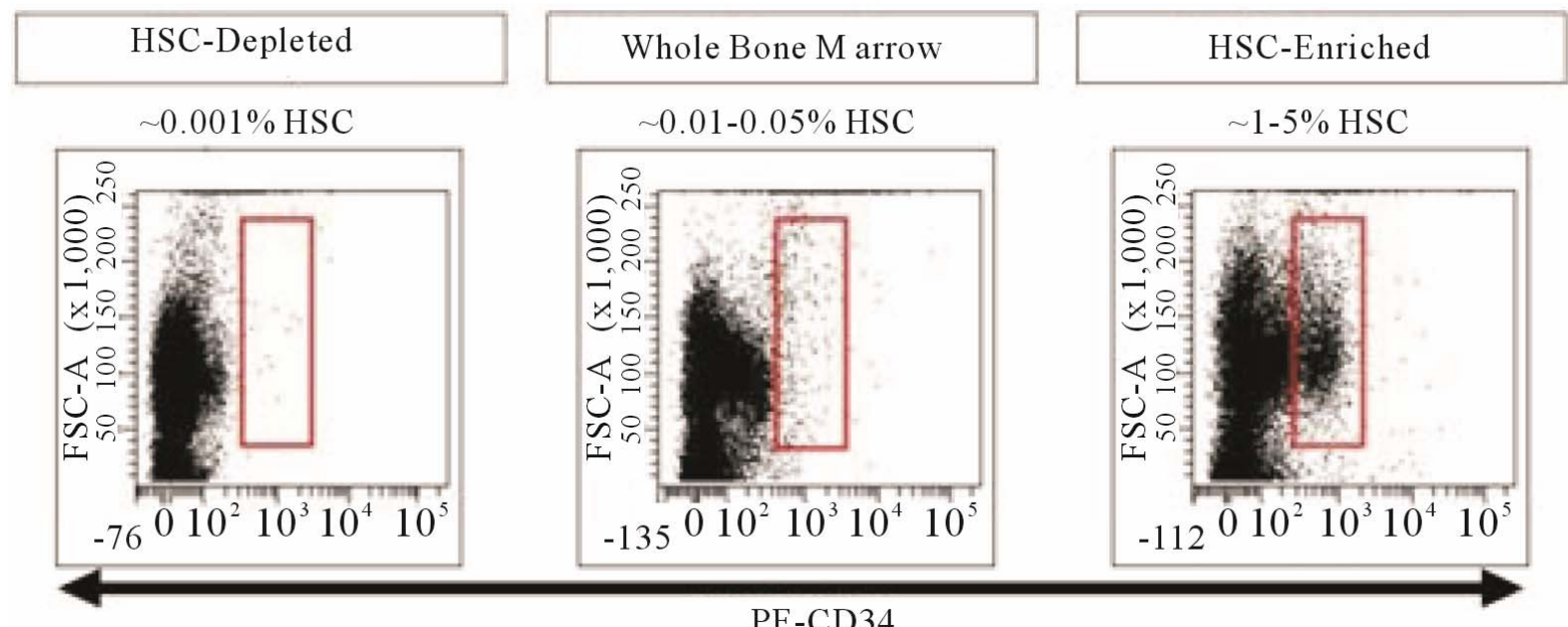

Figure 1. Sample FACS analysis of the different bone marrow derived samples used in this study. The rectangle represents the $\mathrm{CD} 34^{+}$cells as a component of the live $\mathrm{Lin}^{\mathrm{Neg}}$ population of WBM. Relative numbers of HSC $\left(\mathrm{CD} 34^{+} \mathrm{Lin}^{\mathrm{Neg}}\right.$ ) are expressed as a percentage of the total number of live cells.

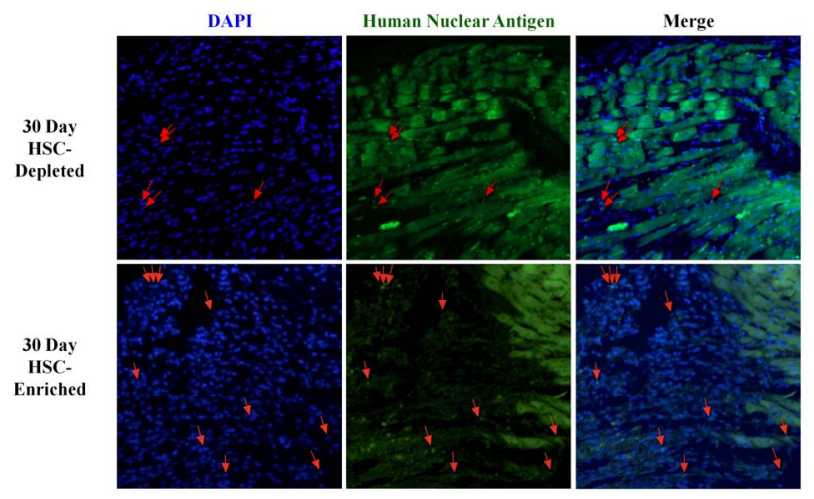

Figure 2. Assessment of the retention of transplanted BM cells within the peri-infarct zone of treated hearts. Co-staining of DAPI and human nuclear antigen (HNA) in the peri-infarct area of hearts that received either the HSC-depleted or HSCenriched samples is selectively illustrated by red arrows.

those observed prior to infarct induction $(P>0.05$, Figures 3(a) and (c)). Analysis of ejection fraction of the left ventricle showed a similar pattern of the effect of HSC on heart function for the different groups to that observed in the LVFS analysis (Figures 3(b) and (c)). A significant difference was observed between the HSC enriched groups and all other groups for both the LVEF and LVFS endpoints. No significant difference $(P>0.05)$ was observed between groups receiving sham MACS processed and unprocessed WBM samples for either LVFS or LVEF (Figures S1(a) and (b)).

\subsection{Analysis of the Relative Contribution of HSC to Cardiac Tissue Recovery Following Induced Myocardial Infarction}

It is well established that myocardial infarction of the

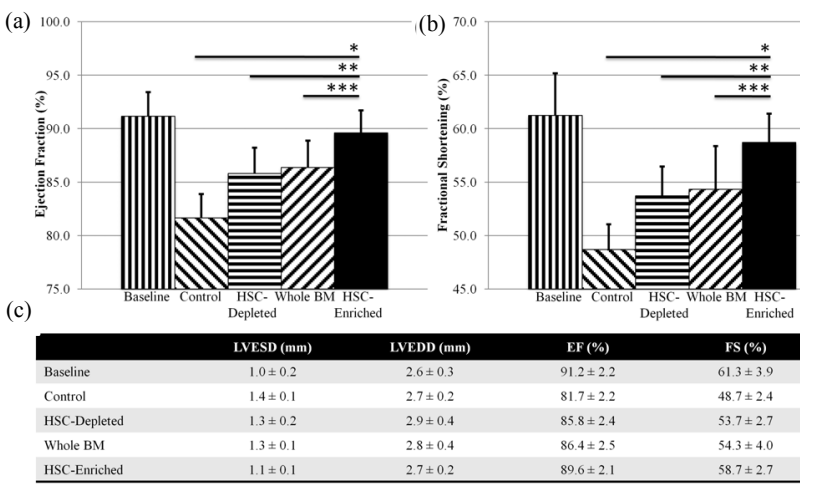

Figure 3. Analysis of in vivo heart function using echocardiography. Quantitative analysis of cardiac function using left ventricular fractional shortening (a) and left ventricular ejection fraction (b); Groups receiving control, HSC-depleted and WBM samples showed a significant reduction $(P<0.05)$ in function from baseline. The group receiving $\mathrm{HSC}$-enriched samples showed significant $(P<0.05)$ improvement in $\mathrm{EF}$ when compared to the control $\left({ }^{*}\right)$, HSC-depleted $\left(^{* *}\right)$, and whole $\mathrm{BM}\left({ }^{* * *}\right)$ sample receiving groups. A summarization of echocardiographic data including left ventricular end-systolic (LVESD) and end-diastolic (LVEDD) dimensions is shown in (c).

left ventricle is associated with weakening and thinning of the left ventricular wall. We assessed whether HSC play a role in facilitating the recovery of cardiac wall thickness after treatment of an induced infarction with bone marrow. Infarct size was assessed by Mason's Trichrome staining of collagen deposition, and midline infarct lengths were measured as previously described [29] (Figure 4(a)). The group receiving HSC-enriched samples showed a significant reduction in infarct size when compared to each of the other groups $(P<0.05$, Figures 4(b)). 
(a)

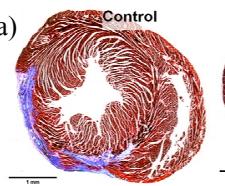

(b)

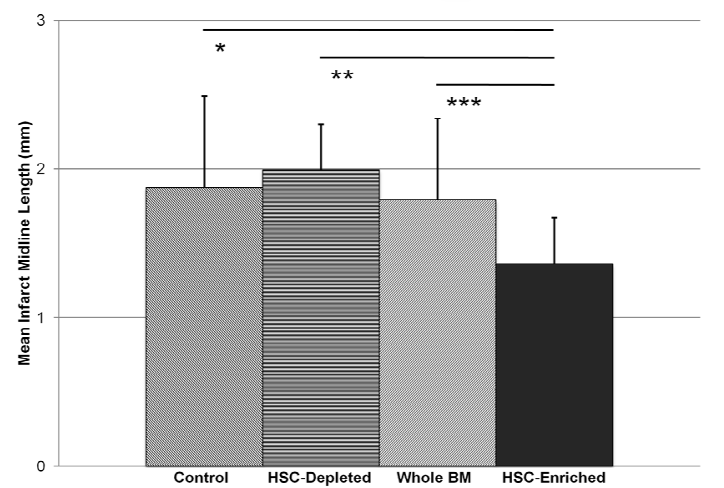

Figure 4. Analysis of the effect of HSC dosage within transplanted BM samples on infarct size four weeks post-transplant. (a) Representative section of hearts from each treatment group (the same mice as assessed in Figure 2 stained with Mason's trichrome. Images illustrate the differences in the myocardial scarring of hearts from different treatment groups. Scale bars (1 $\mathrm{mm}$ ) are shown; (b) Quantitative analysis of infarct size as assessed by measurement of the midline lengths of the infarct zone. The group receiving HSC-enriched samples had significantly less scarring compared with the groups receiving Control $\left({ }^{*} P<0.05\right)$, HSC-depleted $\left({ }^{* * *} P<0.01\right)$, and WBM $\left({ }^{* * * *} P<0.05\right)$ samples.

\subsection{Analysis of the Relative Contribution of HSC to Facilitation of Revascularization in the Infarct Area Following Induced Myocardial Infarction}

Previous studies have suggested that stem cell samples used to treat myocardial infarction promote neo-vascularization, and that this may be responsible for the regenerative effects of these treatments $[21,22,31,32]$. To determine more conclusively whether HSC are responsible for this revascularization following bone marrow cell treatment, we analyzed the density of capillaries in the peri-infarct zone of infarcted hearts one month after treatment (Figure 5(a)). Comparison of isolectin and trichrome images facilitated capillary density analysis in the peri-infarct zone. Capillary density was measured as the mean number of capillaries per 100 square micrometers. There was a clear trend of increasing capillary density as a function of the number of HSC transplanted. In particular, the groups receiving either WBM samples or HSC M-enriched samples had significantly higher periinfarct capillary density than the group receiving HSCdepleted samples $(\mathrm{P}<0.01)$ or the control group $(\mathrm{P}<$ 0.01 ) (Figure 5(b)). No significant difference in capillary density was observed between the groups receiving sham MACS processed WBM and WBM samples $(\mathrm{P}>0.05$, Figure S1(c)).

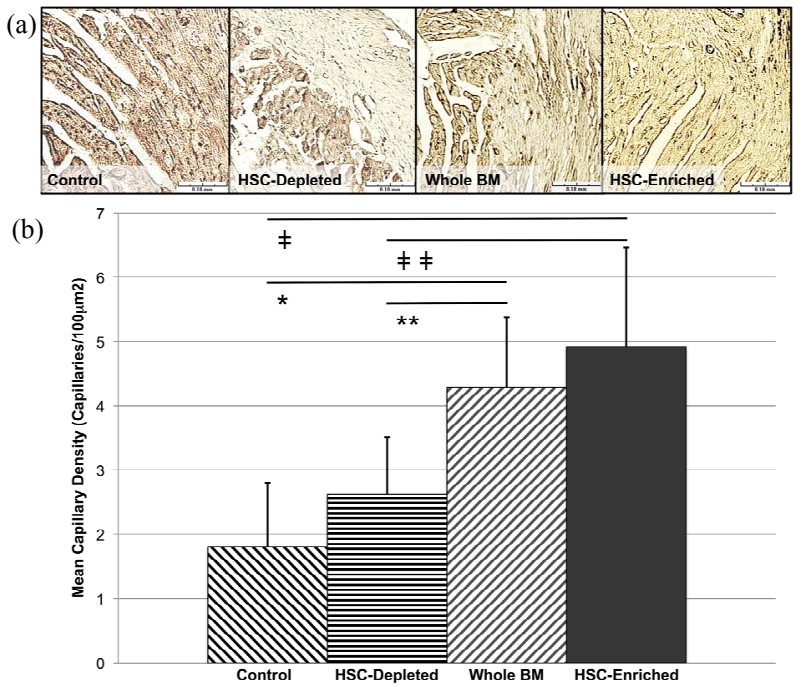

Figure 5. Analysis of the effect of HSC dosage within transplanted BM samples on neovascularization within the infarct zone. Analysis was performed on the same mice as were assessed in Figures 1 and 2. (a) Analysis of capillary density within the infarct zone. Examples of Isolectin B4 staining illustrate differences in peri-infarct zone capillary density. Infarcted tissue is the paler area in the upper right of each image; (b) Quantitative analysis of the mean capillary density in the peri-infarct zone. There was no difference between the groups receiving control and HSC-depleted samples $(P \geq 0.1)$, or WBM and HSC-enriched samples $(P \geq 0.1)$. Significant differences were observed between the groups receiving HSC-enriched and control samples $\left({ }^{\ddagger} P<0.01\right)$, and HSC-enriched and HSC-depleted samples $\left({ }^{\sharp} P<0.01\right)$. There were also significant differences between the groups receiving WBM and control samples $\left({ }^{*} P<0.01\right)$, and WBM and HSC-depleted samples $\left({ }^{* *} P\right.$ $<0.01)$.

\section{DISCUSSION}

In the last decade the possibility of stem cell treatment for heart disease, the world's most pervasive non-infectious ailment has gone from a novel paradigm shift to full-scale clinical trials. We have now determined by rigorous assessment that $\mathrm{HSC}$ have a specific role as a component of the treatment of MI with BM aspirates. Our data show a strong relationship between the proportion of HSC in samples of human bone marrow delivered by intramyocardial injection into infarcted hearts and the regeneration of the myocardium. A $\sim 10$-fold reduction in HSC removed the pro-angiogenic potential of bone marrow treatment (Figure 5(b)) and hearts receiving these samples showed reduced recovery of heart function (Figure 3). Conversely, a $\sim 100$-fold increase in HSC elicited improvement in LVEF and a pro-angiogenic response, and also significantly decreased the scarring of the left ventricle after MI (Figure 4(b)).

Our findings are consistent with the dose-dependent functional improvements observed in the clinic following intracoronary infusion of autologous $\mathrm{CD} 34^{+}$cells in AMI 
patients [23]. Circulating human $\mathrm{CD}^{+} 4^{+}$cells also contain a small fraction of endothelial progenitor cells (EPC) [33]. A previous investigation [22] has suggested a therapeutic potential of highly purified $\mathrm{CD} 34^{+} \mathrm{EPCs}$, derived from circulating mononuclear cells, in the treatment of cardiac infarcts. A low frequency of murine bone marrow $\mathrm{CD}_{3} 4^{+}$cells have been shown to exhibit EPC characteristics [34], and EPC are known to have proangiogenic effects which can positively affect the outcome of ischemia [22].

Our cell collection and enrichment protocol leads to strong enrichment or depletion of HSC, as assessed by limit dilution $\mathrm{CAFC}$ analysis of $\mathrm{CD} 34^{+} \mathrm{Lin}^{\mathrm{Neg}}$ bone marrow-derived cells used in this study (Figure S2). However, we cannot totally exclude potential contributions from the small number of EPC in human bone marrow. There has been controversy over the possible efficacy and mechanism of BM treatment of MI focused around the persistence and function of stem cells in the myocardium $[7,8,35]$, with findings both dismissing and supporting the trans-differentiation of non-cardiac lineage stem cells into functional cardiomyocytes and endothelial tissue. Despite these contradictions, there is a growing body of data from studies of bone marrow derived cell transplantation post-MI in animal models [9,36-38] and human clinical trials $[2,14,23,39-42]$ that show improvements in heart function over the short and long term consistent enough to be retained in extensive meta-analysis [24]. The variability in reported data highlight the need to better understand what makes some cellular therapies successful whilst others effect no improvement. We did not evaluate the molecular mechanisms of the transplanted HSC, however evidence has emerged in support of the hypothesis that a significant potential therapeutic effect of transplanted adult stem cells in cardiac repair is the mediation of paracrine mechanisms by secreted factors (e.g. Protein Kinase B (Akt), endothelial NO synthase (eNOS), vascular endothelial growth factor (VEGF), angiopoietin (Ang-1), Macrophage migration inhibitory factor (MIF)) that may play cardio-protective, anti-apoptotic, and pro-angiogenic roles $[9,38,43]$. It remains to be assessed how other accessible sources of adult stem cells, for example adipose-derived stem cells, perform relative to HSC in therapies to facilitate recovery from MI. The finding that B-cells have cardioprotective effects in the short term [44] make it clear that there is more to BM mononuclear cell treatments than stem cells and demonstrates the need to better understand the roles of the constituent cells of bone marrow.

Bone marrow derived HSC have been observed to contribute to angiogenesis in cardiac ischemia models $[21,22]$. However, the search for the most therapeutically effective stem cell population within the bone marrow has led many researchers to hypothesize that the MSC, being more plastic and having the capacity to differentiate into myocytes $[45,46]$, are principally responsible for regeneration of the myocardium. Hence, considerable research has been dedicated to the study of BM MSC [45-50] based on the assumption that their multi-lineage potential make them more likely candidates for enhancing cardiogenic repair than HSC. We have assessed the relative contribution of HSC within the context of the whole $\mathrm{BM}$ aspirate, and our data from mice receiving BM samples depleted of HSC (Figures 3-5) suggest that human bone marrow HSC are largely responsible for the recovery reported in cell-based MI therapy. MSC may [51], or may not [25], have greater regenerative capacity than HSC. However the lower relative numbers of non-hematopoietic stem cells [52] in the bone marrow extracted for cell-based therapy may relegate the regenerative contribution of these cells to a small role in circumstances using whole bone marrow. This characteristic also makes it difficult to use MSC in time-critical practical situations. While the selection criteria we employed for the enrichment of HSC (the CD34 ${ }^{+} \mathrm{Lin}^{\mathrm{Neg}}$ subpopulation of WBM) does not exclude the presence or possible therapeutic effect of MSC in our bone marrow derived samples, in vitro functional analysis using the CAFC assay showed a marked enrichment of HSC in the $\mathrm{CD}^{4}{ }^{+} \mathrm{Lin}^{\mathrm{Neg}}$ population (Figure S1), that was specifically modified in our samples, as opposed to MSC which do not form cobblestone colonies in this assay [30].

In conclusion, we have shown that despite previous conflicting reports on the use of HSC, selective alteration in relative numbers of HSC within human BM samples transplanted into infarcted hearts has profound affects on the recovery from MI. By recognizing the importance of this accessible stem cell population in the treatment of MI, we suggest that the minimal processing required for HSC enrichment of autologous bone marrow make this a viable strategy for increasing the efficacy of treatments in the clinical setting.

\section{ACKNOWLEDGEMENTS}

This work was supported by Department of Defense grant \#W81XWH-09-2-0012 to R.A. We thank Diane Kumashiro of the Hawaii Transplant Center and Alex Gurary in the Tropical Medicine Department at University of Hawaii for excellent technical assistance.

\section{REFERENCES}

[1] World Health Organization Fact Sheet N317. http://www.who.int/mediacentre/factsheets/fs317/en/inde x.html

[2] Assmus, B., Schächinger, V., Teupe, C., Britten, M., Lehmann, R., Dobert, N., Grunwald, F., Aicher, A., Urbich, C., Martin, H., Hoelzer, D., Dimmeler, S. and Zeiher, 
A.M. (2002) Transplantation of progenitor cells and regeneration enhancement in acute myocardial infarction (TOPCARE-AMI). Circulation, 106, 3009-3017. doi:10.1161/01.CIR.0000043246.74879.CD

[3] Fuchs, S. Satler, L.F., Kornowski, R., Okubagzi, P., Weisz, G., Baffour, R., Waksman, R., Weissman, N.J., Cerqueira, M., Leon, M.B. and Epstein, S.E. (2003) Catheter-based autologous bone marrow myocardial injection in no-option patients with advanced coronary artery disease, Journal of the American College of Cardiology, 41, 1721-1724. doi:10.1016/S0735-1097(03)00328-0

[4] Schächinger, V., Erbs, S., Elsässer, A., Haberbosch, W., Hambrecht, R., Hölschermann, H., Yu, J., Corti, R., Mathey, D.G., Hamm, C.W., Süselbeck, T., Assmus, B., Tonn, T., Dimmeler, S. and Zeiher, A.M. (2006) Intracoronary bone marrow-derived progenitor cells in acute myocardial infarction. The New England Journal of Medicine, 355, 1210-1221. doi:10.1056/NEJMoa060186

[5] Williams, A.R., Trachtenberg, B., Velazquez, D.L., McNiece, I., Altman, P., Rouy, D., Mendizabal, A.M., Pattany, P.M., Lopera, G.A., Fishman, J., Zambrano, J.P., Heldman, A.W. and Hare, J.M. (2011) Intramyocardial stem cell injection in patients with ischemic cardiomyopathy: Functional recovery and reverse remodeling. Circulation Research, 108, 792-796. doi:10.1161/CIRCRESAHA.111.242610

[6] Landmesser, U. (2009) Bone marrow cell therapy after myocardial infarction. What should we select? European Heart Journal, 30, 1310-1312. doi:10.1093/eurheartj/ehp181

[7] Alvarez-Dolado, M., Pardal, R., Garcia-Verdugo, J.M., Fike, J.R., Lee, H.O., Pfeffer, K., Lois, C., Morrison, S.J. and Alvarez-Buylla, A. (2003) Fusion of bone-marrowderived cells with Purkinje neurons, cardiomyocytes and hepatocytes. Nature, 425, 968-973. doi:10.1038/nature 02069

[8] Murry, C.E., Soonpaa, M.H., Reinecke, H., Nakajima, H., Nakajima, H.O., Rubart, M., Pasumarthi, K.B.S., Virag, J.I., Bartelmez, S.H., Poppa, V., Bradford, G., Dowell, J.D., Williams, D.A. and Field, L.J. (2004) Haematopoietic stem cells do not transdifferentiate into cardiac myocytes in myocardial infarcts. Nature, 428, 664-668. doi:10.1038/nature02446

[9] Uemura, R., Xu, M., Ahmad, N. and Ashraf, M. (2006) Bone marrow stem cells prevent left ventricular remodeling of ischemic heart through paracrine signaling. Circulation Research, 98, 1414-1421. doi:10.1161/01.RES.0000225952.61196.39

[10] Baum, C.M., Weissman, I.L., Tsukamoto, S., Buckle, M. and Peault, B. (1992) Isolation of a candidate human hematopoietic stem-cell population. Proceedings of the $\mathrm{Na}$ tional Academy of Sciences of the United States of America, 89, 2804-2808. doi:10.1073/pnas.89.7.2804

[11] Yin, B.A.H., Miraglia, S., Zanjani, E.D., Almeida-Porada, G., Ogawa, M., Leary, A.G., Olweus, J., Kearney, J. and Buck, D.W. (1997) AC133, a Novel Marker for Human Hematopoietic Stem and Progenitor Cells. Blood, 90, 5002-5012.

[12] Terstappen, L.W., Huang, S., Safford, M., Lansdorp, P.M. and Loken, M.R. (1991) Sequential generations of hematopoietic colonies derived from single nonlineage-committed CD34 ${ }^{+}$CD38-progenitor cells. Blood, 77, 12181227.

[13] Herbots, L., D’Hooge, J., Eroglu, E., Thijs, D., Ganame, J., Claus, P., Dubois, C., Theunissen, K., Bogaert, J., Dens, J., Kalantzi, M., Dymarkowski, S., Bijnens, B., Belmans, A., Boogaerts, M., Sutherland, G., Van de Werf, F., Rademakers, F. and Janssens, S. (2009) Improved regional function after autologous bone marrow-derived stem cell transfer in patients with acute myocardial infarction: A randomized, double-blind strain rate imaging study. European Heart Journal, 30, 662-670. doi:10.1093/eurheartj/ehn532

[14] Schächinger, V., Erbs, S., Elsässer, A., Haberbosch, W., Hambrecht, R., Hölschermann, H., Yu, J., Corti, R., Mathey, D.G., Hamm, C.W., Süselbeck, T., Werner, N., Haase, J., Neuzner, J., Germing, A., Mark, B., Assmus, B., Tonn, T., Dimmeler, S. and Zeiher, A.M. (2006) Improved clinical outcome after intracoronary administration of bone-marrow-derived progenitor cells in acute myocardial infarction: Final 1-year results of the REPAIR-AMI trial. European Heart Journal, 27, 2775-2783. doi:10.1093/eurheartj/ehl388

[15] Fernández-Avilés, F., San Román, J.A., García-Frade, J., Fernández, M.E., Peñarrubia, M.J., De la Fuente, L., Gómez-Bueno, M., Cantalapiedra, A., Fernández, J., Gutierrez, O., Sánchez, P.L., Hernández, C., Sanz, R., García-Sancho, J. and Sánchez, A. (2004) Experimental and clinical regenerative capability of human bone marrow cells after myocardial infarction. Circulation Research, 95, 742-748. doi:10.1161/01.RES.0000144798.54040.ed

[16] Lunde, K., Solheim, S., Aakhus, S., Arnesen, H., Abdelnoor, M., Egeland, T., Endresen, K., Ilebekk, A., Mangschau, A., Fjeld, J.G., Smith, H.J., Taraldsrud, E., Grøgaard, H.K., Bjørnerheim, R., Brekke, M., Müller, C., Hopp, E., Ragnarsson, A., Brinchmann, J.E. and Forfang, K. (2006) Intracoronary injection of mononuclear bone marrow cells in acute myocardial infarction. New England Journal of Medicine, 355, 1199-1209. doi:10.1056/NEJMoa055706

[17] Janssens, S., Dubois, C., Bogaert, J., Theunissen, K., Deroose, C., Desmet, W., Kalantzi, M., Herbots, L., Sinnaeve, P., Dens, J., Maertens, J., Rademakers, F., Dymarkowski, S., Gheysens, O., Van Cleemput, J., Bormans, G., Nuyts, J., Belmans, A., Mortelmans, L., Boogaerts, M. and Van de Werf, F. (2006) Autologous bone marrow-derived stem-cell transfer in patients with ST-segment elevation myocardial infarction: Double-blind, randomised controlled trial. Lancet, 367, 113-121. doi:10.1016/S0140-6736(05)67861-0

[18] Perin, W.J. (2012) Effect of transendocardial delivery of autologous bone marrow mononuclear cells on functional capacity, left ventricular function, and perfusion in chronic heart failure: The focus-cctrn trial. JAMA: The Journal of the American Medical Association, 307, 1717-1726. doi:10.1001/jama.2012.418

[19] Wojakowski, W., Tendera, M., Zebzda, A., Michalowska, A., Majka, M., Kucia, M., Maslankiewicz, K., Wyderka, 
R., Król, M., Ochala, A., Kozakiewicz, K. and Ratajczak, M.Z. (2006) Mobilization of CD34( $\left(^{+}\right), \mathrm{CD} 117\left(^{+}\right), \mathrm{CXCR} 4\left(^{+}\right)$, c-met $\left({ }^{+}\right)$stem cells is correlated with left ventricular ejection fraction and plasma NT-proBNP levels in patients with acute myocardial infarction. European Heart Journal, 27, 283-289. doi:10.1093/eurheartj/ehi628

[20] Engelmann, M.G., Theiss, H.D., Hennig-Theiss, C., Huber, A., Wintersperger, B.J., Werle-Ruedinger, A.-E., Schoenberg, S.O., Steinbeck, G. and Franz, W.-M. (2006) Autologous bone marrow stem cell mobilization induced by granulocyte colony-stimulating factor after subacute ST-segment elevation myocardial infarction undergoing late revascularization: Final results from the G-CSFSTEMI (Granulocyte Colony-Stimulating. Journal of the American College of Cardiology, 48, 1712-1721. doi:10.1016/i.jacc.2006.07.044

[21] Iwasaki, H., Kawamoto, A., Ishikawa, M., Oyamada, A., Nakamori, S., Nishimura, H., Sadamoto, K., Horii, M., Matsumoto, T., Murasawa, S., Shibata, T., Suehiro, S. and Asahara, T. (2006) Dose-dependent contribution of CD34-positive cell transplantation to concurrent vasculogenesis and cardiomyogenesis for functional regenerative recovery after myocardial infarction. Circulation, 113, 1311-1325. doi:10.1161/CIRCULATIONAHA.105.541268

[22] Kawamoto, A., Iwasaki, H., Kusano, K., Murayama, T., Oyamada, A., Silver, M., Hulbert, C., Gavin, M., Hanley, A., Ma, H., Kearney, M., Zak, V., Asahara, T. and Losordo, D.W. (2006) CD34-positive cells exhibit increased potency and safety for therapeutic neovascularization after myocardial infarction compared with total mononuclear cells. Circulation, 114, 2163-2169. doi:10.1161/CIRCULATIONAHA.106.644518

[23] Quyyumi, A.A., Waller, E.K., Murrow, J., Esteves, F., Galt, J., Oshinski, J., Lerakis, S., Sher, S., Vaughan, D., Perin, E., Willerson, J., Kereiakes, D., Gersh, B.J., Gregory, D., Werner, A., Moss, T., Chan, W.S., Preti, R. and Pecora, A.L. (2011) CD34 ${ }^{+}$cell infusion after ST elevation myocardial infarction is associated with improved perfusion and is dose dependent. American Heart Journal, 161, 98-105. doi:10.1016/j.ahj.2010.09.025

[24] Delewi, R., Andriessen, A., Tijssen, J.G.P., Zijlstra, F., Piek, J.J. and Hirsch, A. (2012) Impact of intracoronary cell therapy on left ventricular function in the setting of acute myocardial infarction: A meta-analysis of randomised controlled clinical trials. Heart, 99, 225-232. doi:10.1136/heartjnl-2012-302230

[25] Van der Bogt, K.E.A., Sheikh, A.Y., Schrepfer, S., Hoyt, G., Cao, F., Ransohoff, K.J., Swijnenburg, R.-J., Pearl, J., Lee, A., Fischbein, M, Contag, C.H., Robbins, R.C. and Wu, J.C. (2008) Comparison of different adult stem cell types for treatment of myocardial ischemia. Circulation, 118, S121-S129.

doi:10.1161/CIRCULATIONAHA.107.759480

[26] Ma, N., Ladilov, Y., Moebius, J.M., Ong, L., Piechaczek, C., Dávid, A., Kaminski, A., Choi, Y.-H., Li, W., Egger, D., Stamm, C. and Steinhoff, G. (2006) Intramyocardial delivery of human $\mathrm{CD} 133^{+}$cells in a SCID mouse cryoinjury model: Bone marrow vs. cord blood-derived cells. Cardiovascular Research, 71, 158-169.

\section{doi:10.1016/j.cardiores.2006.03.020}

[27] Naseem, R.H., Meeson, A.P., Dimaio, J.M., White, M.D., Kallhoff, J., Humphries, C., Goetsch, S.C., De Windt, L.J., Williams, M.A., Garry, M.G. and Garry, D.J. (2007) Reparative myocardial mechanisms in adult C57BL/6 and MRL mice following injury. Physiological Genomics, 30, 44-52. doi:10.1152/physiolgenomics.00070.2006

[28] Bos, E.J.V.D., Mees, B.M.E., de Waard, M.C., de Crom, R. and Duncker, D.J. (2005) A novel model of cryoinjury-induced myocardial infarction in the mouse: A comparison with coronary artery ligation. American Journal of Physiology-Heart and Circulartory Physiology, 289, H1291-H1300. doi:10.1152/ajpheart.00111.2005

[29] Takagawa, J., Zhang, Y., Wong, M.L., Sievers, R.E., Kapasi, N.K., Wang, Y., Yeghiazarians, Y., Lee, R.J., Grossman, W. and Springer, M.L. (2007) Myocardial infarct size measurement in the mouse chronic infarction model: Comparison of area- and length-based approaches. Journal of Applied Physiology, 102, 2104-2111. doi:10.1152/japplphysiol.00033.2007

[30] Denning-Kendall, P., Singha, S., Bradley, B. and Hows, J. (2003) Cobblestone area-forming cells in human cord blood are heterogeneous and differ from long-term culture-initiating cells. Stem Cells, 21, 694-701. doi:10.1634/stemcells.21-6-694

[31] Kwon, S.-M., Lee, Y.-K., Yokoyama, A., Jung, S.-Y., Masuda, H., Kawamoto, A., Lee, Y.M. and Asahara, T. (2011) Differential activity of bone marrow hematopoietic stem cell subpopulations for EPC development and ischemic neovascularization. Journal of Molecular and Cellular Cardiology, 51, 308-317. doi:10.1016/j.yimcc.2011.04.007

[32] Valina, C., Pinkernell, K., Song, Y.-H., Bai, X., Sadat, S., Campeau, R.J., Le Jemtel, T.H. and Alt, E. (2007) Intracoronary administration of autologous adipose tissue-derived stem cells improves left ventricular function, perfusion, and remodelling after acute myocardial infarction. European Heart Journal, 28, 2667-2677. doi:10.1093/eurheartj/ehm426

[33] Peichev, M., Naiyer, A.J., Pereira, D., Zhu, Z., Lane, W.J., Williams, M., Oz, M.C., Hicklin, D.J., Witte, L., Moore, M.A. and Rafii, S. (2000) Expression of VEGFR-2 and AC133 by circulating human $\mathrm{CD}^{2} 4\left(^{+}\right)$cells identifies a population of functional endothelial precursors. Blood, 95, 952-958

[34] Yang, J., Ii, M., Kamei, N., Alev, C., Kwon, S.-M., Kawamoto, A., Akimaru, H., Masuda, H., Sawa, Y. and Asahara, T. (2011) $\mathrm{CD}^{+} 4^{+}$cells represent highly functional endothelial progenitor cells in murine bone marrow. PloS One, 6, e20219. doi:10.1371/journal.pone.0020219

[35] Agbulut, O., Mazo, M., Bressolle, C., Gutierrez, M., Azarnoush, K., Sabbah, L., Niederlander, N., Abizanda, G., Andreu, E.J., Pelacho, B., Gavira, J.J., Perez-Ilzarbe, M., Peyrard, S., Bruneval, P., Samuel, J., SorianoNavarro, M., García-verdugo, J.M., Hagège, A.A., Prósper, F. and Menasché, P. (2006) Can bone marrowderived multipotent adult progenitor cells regenerate infarcted myocardium? Cadiovascular Research, 72, 175183. doi:10.1016/j.cardiores.2006.07.009 
[36] Orlic, D., Kajstura, J., Chimenti, S., Jakoniuk, I., Anderson, S.M., Li, B., Pickel, J., Mckay, R., Nadal-Ginard, B., Bodine, D.M., Leri, A. and Anversa, P. (2001) Bone marrow cells regenerate infarcted myocardium. Nature, $\mathbf{4 1 0}$, 701-705. doi:10.1038/35070587

[37] Kocher, A.A., Schuster, M.D., Szabolcs, M.J., Takuma, S., Burkhoff, D., Wang, J., Homma, S., Edwards, N.M. and Itescu, S. (2001) Neovascularization of ischemic myocardium by human bone-marrow-derived angioblasts prevents cardiomyocyte apoptosis, reduces remodeling and improves cardiac function. Nature Medicine, 7, 430-436. doi: $10.1038 / 86498$

[38] Kamihata, H., Matsubara, H., Nishiue, T., Fujiyama, S., Tsutsumi, Y., Ozono, R., Masaki, H., Mori, Y., Iba, O., Tateishi, E., Kosaki, A., Shintani, S., Murohara, T., Imaizumi, T. and Iwasaka, T. (2001) Implantation of bone marrow mononuclear cells into ischemic myocardium enhances collateral perfusion and regional function via side supply of angioblasts, angiogenic ligands, and cytokines. Circulation, 104, 1046-1052. doi:10.1161/hc3501.093817

[39] Hirsch, A., Nijveldt, R., van der Vleuten, P.A., Tio, R.A., van der Giessen, W.J., Marques, K.M., Doevendans, P.A., Waltenberger, J., Ten Berg, J.M., Aengevaeren, W.R., Biemond, B.J., Tijssen, J.G., van Rossum, A.C., Piek, J.J. and Zijlstra, F. (2008) Intracoronary infusion of autologous mononuclear bone marrow cells in patients with acute myocardial infarction treated with primary PCI: Pilot study of the multicenter HEBE trial. Catheterization and Cardiovascular Interventions, 71, 273-281. doi:10.1002/ccd.21337

[40] Meluzín, J., Janousek, S., Mayer, J., Groch, L., Hornácek, I., Hlinomaz, O., Kala, P., Panovský, R., Prásek, J., Kamínek, M., Stanícek, J., Klabusay, M., Korístek, Z., Navrátil, M., Dusek, L. and Vinklárková, J. (2008) Three-, 6-, and 12-month results of autologous transplantation of mononuclear bone marrow cells in patients with acute myocardial infarction. International Journal of Cardiology, 128, 185-192. doi:10.1016/j.ijcard.2007.04.098

[41] Strauer, B.E., Brehm, M., Zeus, T., Kostering, M., Hernández, A., Sorg, R., Kogler, G. and Wernet, P. (2002) Repair of infarcted myocardium by autologous intracoronary mononuclear bone marrow cell transplantation in humans. Circulation, 106, 1913-1918. doi:10.1161/01.CIR.0000034046.87607.1C

[42] Yousef, M., Schannwell, C.M., Köstering, M., Zeus, T., Brehm, M. and Strauer, B.E. (2009) The BALANCE study: Clinical benefit and long-term outcome after intracoronary autologous bone marrow cell transplantation in patients with acute myocardial infarction. Journal of the American College of Cardiology, 53, 2262-2269. doi:10.1016/j.jacc.2009.02.051

[43] Gnecchi, M., Zhang, Z., Ni, A. and Dzau, V.J. (2008) Paracrine mechanisms in adult stem cell signaling and therapy. Circulation Research, 103, 1204-1219. doi:10.1161/CIRCRESAHA.108.176826
[44] Goodchild, T.T., Robinson, K.A., Pang, W., Tondato, F., Cui, J., Arrington, J., Godwin, L., Ungs, M., Carlesso, N., Weich, N., Poznansky, M.C. and Chronos, N.A.F. (2009) Bone marrow-derived B cells preserve ventricular function after acute myocardial infarction. JACC: Cardiovascular Interventions, 2, 1005-1016. doi:10.1016/j.jcin.2009.08.010

[45] Toma, C., Pittenger, M.F., Cahill, K.S., Byrne, B.J. and Kessler, P.D. (2002) Human mesenchymal stem cells differentiate to a cardiomyocyte phenotype in the adult murine heart. Circulation, 105, 93-98. doi:10.1161/hc0102.101442

[46] Xu, W., Zhang, X., Qian, H., Zhu, W., Sun, X., Hu, J., Zhou, H. and Chen, Y. (2004) Mesenchymal stem cells from adult human bone marrow differentiate into a cardiomyocyte phenotype in vitro. Experimental Biology and Medicine, 229, 623-631.

[47] Gojo, S., Gojo, N., Takeda, Y., Mori, T., Abe, H., Kyo, S. Hata, J. and Umezawa, A. (2003) In vivo cardiovasculogenesis by direct injection of isolated adult mesenchymal stem cells. Experimental Cell Research, 288, 51-59. doi:10.1016/S0014-4827(03)00132-0

[48] Shyu, K.-G., Wang, B.-W., Hung, H.-F., Chang, C.-C. and Shih, D.T.-B. (2006) Mesenchymal stem cells are superior to angiogenic growth factor genes for improving myocardial performance in the mouse model of acute myocardial infarction. Journal of Biomedical Science, 13, 47-58. doi:10.1007/s11373-005-9038-6

[49] Behfar, A., Yamada, S., Crespo-Diaz, R., Nesbitt, J.J., Rowe, L.A., Perez-terzic, C., Gaussin, V., Homsy, C., Bartunek, J. and Terzic, A. (2010) Guided cardiopoiesis enhances therapeutic benefit of bone marrow human mesenchymal stem cells in chronic myocardial infarction. Journal of the American College of Cardiology, 56, 721-734. doi:10.1016/j.jacc.2010.03.066

[50] Chen, S.L., Fang, W., Ye, F., Liu, Y.H., Qian, J., Shan, S., Zhang, J., Zhao, R.C.H., Liao, L.M., Lin, S. and Sun, J.P. (2004) Effect on left ventricular function of intracoronary transplantation of autologous bone marrow mesenchymal stem cell in patients with acute myocardial infarction. American Journal of Cardiology, 94, 92-95. doi:10.1016/j.amjcard.2004.03.034

[51] Armiñan, A., Gandia, C., Garcia-Verdugo, J.M., Lledo, E., Trigueros, C., Ruiz-sauri, A., Miñana, M.D., Solves, P., Payá, R., Montero, J.A. and Sepúlveda, P. (2010) Mesenchymal stem cells provide better results than hematopoietic precursors for the treatment of myocardial infarction. Journal of the American College of Cardiology, 55, 2244-2253. doi:10.1016/j.jacc.2009.08.092

[52] Seeger, F.H., Tonn, T., Krzossok, N., Zeiher, A.M. and Dimmeler, S. (2007) Cell isolation procedures matter: A comparison of different isolation protocols of bone marrow mononuclear cells used for cell therapy in patients with acute myocardial infarction. European Heart Journal, 28, 766-772. doi:10.1093/eurheartj/eh1509 


\section{SUPPLEMENT}

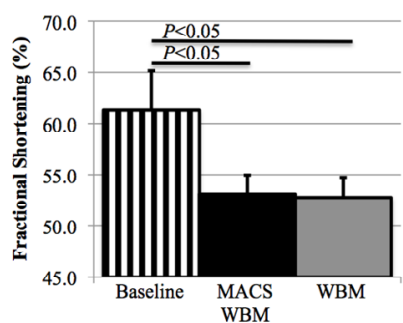

(a)

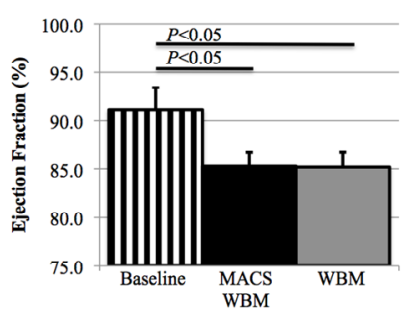

(b)

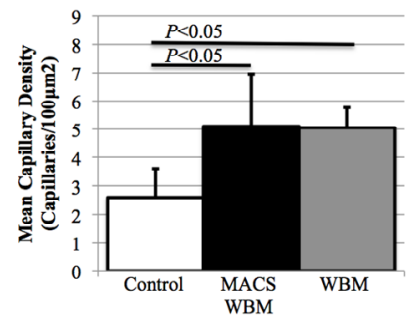

(c)

Figure S1. Analysis of the effect of MACS cell preparation on revascularization, infarct size, and heart function. No significant difference was seen in either LVFS (a) or LVEF (b) between groups receiving WBM sham processed with MACS or not; (c) Mean peri-infarct capillary density 30 days post infarction and cell transplantation for groups receiving WBM either processed by MACS or not showed no significant difference between preparation methods.

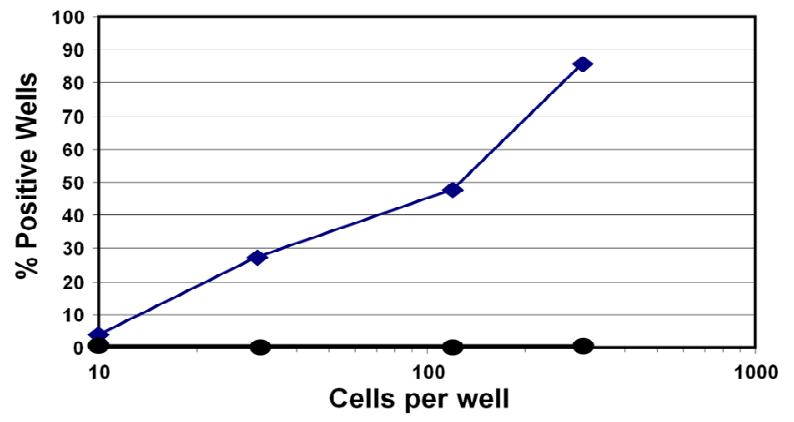

Figure S2. In vitro analysis of HSC frequency in the CD $34^{+}$ LinNeg bone marrow population by limit dilution analysis of CAFC. The CAFC assay was performed as described previously. The number of $\mathrm{CD} 34^{+} \mathrm{Lin}^{\mathrm{Neg}}$ cells FACS sorted into wells of a 96-well plate is shown on the $\mathrm{x}$-axis. Each data point represents average value from in triplicate analysis.
Table S1. Lineage markers present in lineage selection kit. A list of the lineage positive selection markers present within the lineage selection kit, and their corresponding cellular functions and cell-specific expression.

\begin{tabular}{cc}
\hline $\begin{array}{c}\text { Hematopoietic } \\
\text { lineage antibody }\end{array}$ & Marker function \\
\hline CD2 & T-, and NK cell adhesion molecule \\
CD3 & T-cell co-receptor \\
CD11b & Leukocyte inflammatory mediator \\
CD14 & Monocyte LPS co-receptor \\
CD15 & Neutrophil \& eosinophil adhesion molecule \\
CD16 & Monocyte, macrophage \& NK cell Fc receptor \\
CD19 & B-cell co-receptor \\
CD56 & NK-cell adhesion molecule \\
CD123 & Dendritic cell \& granulocyte cytokine receptor \\
CD235a & Erythroid cell transmembrane glycoprotein \\
\hline
\end{tabular}

